\title{
KEY PERFORMANCE INDICATOR APPLICATION BASED ON FORWARD CHAINING ALGORITHM (Case Study: PT Bumi Perkasa)
}

\author{
Kevin Leonardi \\ Faculty of Engineering and Informatics \\ Universitas Multimedia Nusantara \\ kevin.leonardi95@gmail.com
}

\author{
Winarno \\ Faculty of Engineering and Informatics \\ Universitas Multimedia Nusantara \\ pmwinarno@umn.ac.id
}

\begin{abstract}
Performance assessment is one of the important elements for company development. Good performance from employees certainly have a positive impact on the company's growth. However, such rating system is still often underestimated for the continuity of the company's performance. This work aimed to create a system to calculate the Key Performance Indicator (KPI). KPI is a value or result that refers to whether an employee's performance is good or not within a certain timeframe. The calculation will be carried out by utilizing the criteria or rule-based that has been owned by the company, in this case, PT Bumi Perkasa. The concern is the difference of the final calculation results between the previous system and the records, which can be solved by implementing the Forward Chaining algorithm. This application aims to provide better information about the final value of KPI in each field in PT Bumi Perkasa, with the aim of minimizing data errors in the calculation process and results.
\end{abstract}

Keywords: Forward Chaining, Key Performance Indicator, PT Bumi Perkasa, Performance Assessment, Rule Based.

\section{Background}

Performance or productivity assessment is a process of measurement carried out in an organization to achieve its stated objectives. According to [2], the definition of performance is the work of quality and quantity achieved by an employee in carrying out his duties in accordance with the responsibilities given to him. This is driven by the need for information to be an important matter, thus causing business competition to change from competition to the nature of technology to information competition. With the information generated for each activity carried out, the organization will obtain accurate, relevant, and timely data to be used in making a decision [13].

Based on the results of discussions and interviews with Mr. Rizky Muhammad, PT Bumi Perkasa is a manufacturing company engaged in the production of cooking oil made from palm oil. At present PT Bumi Perkasa has an obstacle to the KPI calculation system that is owned, namely the problem in the output of the final result. The constraints referred to here are the final results of calculating KPI in each division through the system there having 
different results compared to the records available at the end of each month through manual calculations. Forward Chaining is a form of method used to find or provide a related conclusion based on data, information, or facts provided. The facts given to the system (in this case the number of absences, the number of delays, and the timeliness of collecting deadline tasks) will be used by the inference engine to find a conclusion by matching information with the existing rules [8]. The forward chaining method is used in order to reach a conclusion (solution), then the rules or premise to be used must be input first [8].

Previous research related to calculating KPI or performance appraisal was conducted by Angela Clara Bernadia Sihotang entitled "Measurement of Company Performance Using the Balanced Scorecard at PT. XYZ "explained that every small company and large company is always required to be able to plan, direct and supervise with the aim to drive the performance potential of the company if it wants to continue to exist and can continue to compete with other companies. However, in this study, Angela used the Balanced Scorecard method which divides benchmarks not only from activities in the company, but also from consumer responses about the company concerned. This method is not suitable for use in the case study of PT. Bumi Perkasa which acts as a manufacturing company, where performance in the company must be considered more than the consumer response. In the case study at PT. Bumi Perkasa, the advantage in using this forward chaining method is that this method can work well in terms of providing lots of information from a small or limited amount of data, in the case of PT. Bumi Perkasa is the end result of KPI calculations that have been done.

To achieve the expected results, a system evaluation process will be carried out using the End-User Computing Satisfaction (EUCS) method. This EUCS method is a method for measuring the level of satisfaction of users of a system or application by comparing the expectations and reality of an information system. The definition of EUCS from an information system is the overall evaluation of users of information systems based on their experience in using the system [5]. Based on the description of the background, the final assignment report was titled "Key Performance Indicator Application Based on Forward Chaining Algorithm".

\section{Materials and Methods}

\section{A. Forward Chaining Algorithm}

The inference strategy of the forward chaining algorithm starts with a set of knowledge facts, acquires new facts using rules where a premise is in accordance with the facts of knowledge, and continues the process until a set goal has been achieved [9]. Broadly speaking, the process while using forward chaining is as follows.

1. The inference strategy begins with a known collection of facts.

2. Obtain new facts using rules whose premises are in accordance with known facts.

3. The process is continued until the goal is reached or until there are no more rules whose premise is in accordance with the facts.

Forward chaining is a fact to get a conclusion from a fact itself [9]. This reasoning is based on existing facts (data driven), this method is the opposite of the backward chaining method, where this method is executed by gathering the facts to draw conclusions. In other words, the process starts from the facts (facts that exist) through the fact inference process (reasoning facts) to get to a goal (goal). This method can also be called using the IF - THEN rule where the premise (IF) goes to a conclusion (THEN). In the forward chaining method, the inference engine will match the facts in the knowledge base to the situation stated in the rules 
in the IF section. If the facts in the knowledge base are in accordance with the IF rules, then the rule is simulated and the next rule will be tested until it reaches conclusions or final results [10].

\section{B. Key Performance Indicator}

The Key Performance Indicator (KPI) is a matrix form, both in financial and nonfinancial terms used by companies to measure their performance [11]. Key Performance Indicators are usually used to assess the condition of a business and what actions are needed to address the condition. During this Key Performance Indicator is used to measure qualitative parameters that tend to be difficult to measure. For example leadership quality and customer satisfaction, but this does not include KPI. The difference in things including KPI or not lies in the contents of the matrix. The Key Performance Indicator matrix explains the performance performance to be achieved by a company and what steps must be taken to realize the strategic object of the company. A matrix will be said as a Key Performance Indicator when meeting the company's standard employee criteria as follows.

1. Quality, prioritizing production results for customer satisfaction and all stakeholders by always providing quality products that can be proud of.

2. Efficiency, the Company may not give unnatural burdens to consumers and stakeholders. Therefore all company unit businesses must always prioritize efficient ways.

3. Innovation, always innovating to provide the best for consumers.

4. Passion, always improve the quality of human resources owned and build cooperation to become a team that is superior, persistent, and not easily satisfied so that they always get better every day.

5. Wisdom and Confidence, do the best as a lifestyle and strive to be the best by working smartly, confidently, and clearly in the direction that is intended.

6. Responsibility, continuously improving work processes and methods to satisfy all relevant parties.

\section{The Rule Based at PT Bumi Perkasa}

\section{Forward Chaining Implementation}

The knowledge base used is rule-based reasoning. The set of rules used in the forward chaining implementation process on the system are described in Table 1 below.

Table 1 The Rule Based used

\begin{tabular}{|c|l|}
\hline No & \multicolumn{1}{|c|}{ Rules } \\
\hline 1 & IF the average score below 60 THEN failed the KPI assessment. \\
\hline 2 & IF the number of rules passed is below 50\% THEN failed the KPI assessment. \\
\hline 3 & IF the mandatory rule value set below 60 THEN failed the KPI assessment. \\
\hline 4 & $\begin{array}{l}\text { IF the average value above 60 AND the number of rules passed is above 50\% AND } \\
\text { the mandatory rule value above 60 THEN passed the KPI assessment. }\end{array}$ \\
\hline
\end{tabular}


As for a set of rules in the description of Table 1, a logical tree can be obtained that illustrates how the flow of the forward chaining algorithm is implemented. The form of the logical tree in question is illustrated in Figure 1 below.

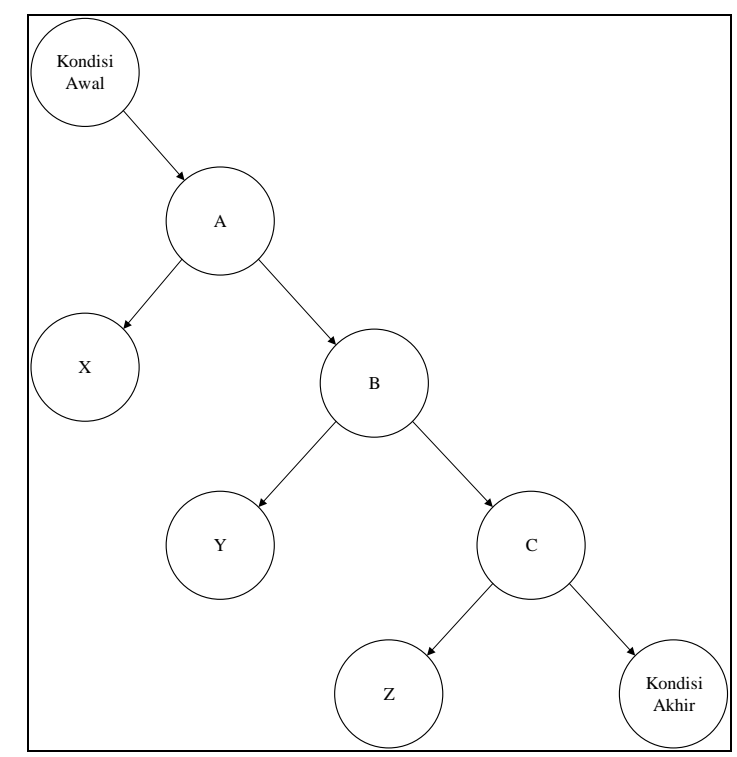

Figure 1 Logical Tree from Forward Chaining that Implemented

In Figure 1 above, the initial condition in question is when the user has finished inputting the KPI value, and the algorithm will begin the calculation process. Condition $\mathrm{A}$ is the first criterion of forward chaining, that is, the final value of the average must have a score above 60. If condition $A$ is not fulfilled, it will lead to condition $X$, that is the assessment fails and if fulfilled it will proceed to the next condition, condition B. Condition B is the second criterion of forward chaining that is implemented, that is, the number of rules that pass on criterion $\mathrm{A}$ must amount to more than $50 \%$ of the total number of existing rules. If this condition is not met, it will lead to the condition of $\mathrm{Y}$, that is, the assessment failed and if condition $\mathrm{B}$ is fulfilled, it will proceed to condition $\mathrm{C}$. The condition $\mathrm{C}$ here is the third criterion implemented in the forward chaining algorithm. This criterion is in the form of a provision whereby mandatory predetermined rules must pass, if it fails it will lead to $\mathrm{Z}$ condition, which is failing in KPI assessment. If conditions $\mathrm{A}, \mathrm{B}$, and $\mathrm{C}$ are all fulfilled and there are no failures, the final condition to be obtained is to pass the KPI assessment.

There are KPI grade determinants and calculation methods performed by PT Bumi Perkasa as described by Mr. Rizky Muhammad through a process of discussion and interviews and data files provided. The rule table described below is a rule found in each departmen of PT Bumi Perkasa, which are Human Resources (HRD), Marketing, Information and Technology (IT), Finance, and Production.

\section{RESULT AND DISCUSSION}

After completing the trial, the questionnaire was submitted in the form of a question based on the EUCS method to measure the level of satisfaction of Mr. Rizky Muhammad as the main user when using this system. According to [15], in answering questions the scale of 
measurement variables refers to the Likert Scale (Likert Scale) where each answer is given a score or weight which is between 1 to 5 , with details as follows.

$>$ The SS (Strongly Agree) answer is given a score of 5 .

$>$ Answer S (Agree) is given a score of 4.

$>$ Answer $\mathrm{N}$ (Neutral) is given a score of 3 .

$>$ Answer TS (Disagree) is given a score of 2.

$>$ The STS (Strongly Disagree) answer is given a score of 1 .

According to [15], as for there is a percentage scale used in classifying the final results of the evaluation as follows.

$>$ The SS (Very Satisfied) category has a percentage of $81 \%$ to $100 \%$.

$>$ Category P (Satisfied) has a percentage of $61 \%$ to $80 \%$.

$>$ Category $\mathrm{N}$ (Neutral) has a percentage of $41 \%$ to $60 \%$.

$>$ The TP category (Unsatisfied) has a percentage of $21 \%$ to $40 \%$.

$>$ The STP (Very Dissatisfied) category has a percentage of $0 \%$ to $20 \%$

The following is a description of the list of questions used in the evaluation or evaluation of the system that has been built.

Table 2 End User Computer Satisfaction

\begin{tabular}{|c|c|c|c|}
\hline No & $\begin{array}{c}\text { EUCS } \\
\text { Dimensions }\end{array}$ & Question & Scores \\
\hline 1 & Content & $\begin{array}{l}\text { - This system provides information according to your needs. } \\
\text { - This system provides complete information. } \\
\text { - This system provides information that is easy to understand. }\end{array}$ & $\begin{array}{l}5 \\
4 \\
4\end{array}$ \\
\hline 2 & Accuracy & $\begin{array}{l}\text { - This system provides data accuracy that fits your needs. } \\
\text { - The buttons and menus contained in the system run } \\
\text { according to their functions. } \\
\text { - KPI data displayed according to needs. }\end{array}$ & 5 \\
\hline 3 & Format & $\begin{array}{l}\text { - The overall system design is interesting. } \\
\text { - Design the appropriate user interface. } \\
\text { - Button design is easy to understand and attractive. } \\
\text { - Suitable color combination. }\end{array}$ & $\begin{array}{l}4 \\
5 \\
5 \\
4\end{array}$ \\
\hline 4 & Ease of Use & $\begin{array}{l}\text { - This system is easy to use. } \\
\text { - It doesn't take long to learn how to use the system. } \\
\text { - KPI data is processed quickly. }\end{array}$ & $\begin{array}{l}4 \\
4 \\
5\end{array}$ \\
\hline 5 & Timeliness & $\begin{array}{l}\text { - Information about the rules and the results of the KPI } \\
\text { assessment needed can be obtained quickly. } \\
\text { - This system displays the appropriate information. }\end{array}$ & 4 \\
\hline & Total & Scores & 67 \\
\hline & & Satisfaction $=67 / 75 \times 100 \%$ & $89.3 \%$ \\
\hline
\end{tabular}

\section{CONCLUSION}

From the implementation of the research it can be concluded that the forward chaining algorithm has been successfully implemented and the system has been completed. After being 
evaluated by Mr. Rizky Muhammad, it is known that the forward chaining algorithm can be used to determine the final result of the Key Performance Indicator calculation process.

Based on the results of the evaluation that has been obtained, it is concluded that the implementation of the forward chaining algorithm in calculating KPI at PT. Bumi Perkasa has been successful and completed. The program has been used well according to information provided by Mr. Rizky Muhammad, with satisfaction rate $89.3 \%$ (very satisfied).

\section{References}

[1] S. M. Metev and V. P. Veiko, Laser Assisted Microtechnology, 2nd ed., R. M. Osgood, Jr., Ed. Berlin, Germany: Springer-Verlag, 1998.

[2] A.A, Anwar Prabu Mangkunegara. (2000). Manajemen Sumber Daya Manusia Perusahaan. Bandung: Penerbit PT. Remaja Rosdakarya.

[3] Chin, W.W, dan Lee, Matthew. K.O. (2000). A Proposed Model and Measurement Instrument for The Information Of Is Satisfaction: The Case Of End-User Computing Satisfaction.

[4] Dalimunthe, N., dan Ismiati, C. (2016). Analisis Tingkat Kepuasan Pengguna Online Public Access Catalog (OPAC) Dengan Metode EUCS (Studi Kasus: Perpustakaan UIN SUSKA Riau). Jurnal Rekayasa dan Manajemen Sistem Informasi, Vol.2, No.1, Februari 2016. Pekanbaru, Riau.

[5] Doll, W.J., dan Torkzadeh, G. (1991). The Measurement of End-User Computing Satisfaction: Theoretical Considerations. MIS Quaterly (15:1).

[6] Durkin, J., (1994). Expert Systems Design and Development, Prentice Hall International Inc., New Jersey.

[7] Dwi Gandhika Supartha, I.K, \& Nirmala Sari, I. (2014). 'Sistem Pakar Diagnosa Awal Penyakit Kulit Pada Sapi Bali dengan Menggunakan Metode Forward Chaining dan Certainty Factor'. Jurnal Nasional Pendidikan Teknik Informatika (JANAPATI) Volume 3, Nomor 3. Denpasar, Bali.

[8] Halim, L. J. (2015). Rancang Bangun Aplikasi Penjurusan Minat Bakat UKM di UMN Dengan Metode Forward Chaining. Tangerang: Universitas Multimedia Nusantara.

[9] Kusumadewi, S. (2003). Artificial Intelligence (Teknik dan Aplikasinya). Graha Ilmu, Yogyakarta.

[10] Perdana, Level, Nugroho, Didik, \& Kustanto. Tanpa Tahun. 'Sistem Pakar untuk Diagnosis Penyakit Ginjal Dengan Metode Forward Chaining'. Jurnal TIKomSIN.

[11] PT. Manajemen Kinerja Utama. (2011). Pengertian Tentang KPIKey Performance Indicator, diakses 12 April 2018, <http://manajemenkinerja.com/2011/11/pengertian-tentang-kpi-key-performance-indicators/ >

[12] Rahab, Sulistyandari, Soedjono. (2011). The Development Of Innovation Capability Of Small Medium Enterprises Through Knowledge Sharing Process: An Empirical Study Of Indonesian Creative Industry. International Journal of Business and Social Science Vol. 2 No. 21 November 2011

[13] Samsudin, Sadili. (2010). Manajemen Sumber Daya Manusia. Bandung: Pustaka Setia.

[14] Sihotang, Angela Clara Bernadia. (2016). Pengukuran Kinerja Perusahaan Menggunakan Balanced Scorecard Pada PT. XYZ. Surabaya: Widya Mandala Chatolic University.

[15] Syarif, Muhammad. (2017). 'Evaluasi Kepuasan User Interface Desain Aplikasi Android Menggunakan End User Computing Satisfaction (EUCS) Pada Aplikasi Android Sciencom'. Jurnal Incomtech, Vol.6, No.1, Juni 2017. Bekasi: Universitas Krisnadwipayana.

[16] Torkamani, Hojjat Mohammadi, Ali Sharifian, Mehdi Rostamzadeh. (2012). Performance Evaluation Using the Balanced Score Card (BSC): A Case Study of Azerbaijan Regional Electric Company. Journal of Basic and Applied Scientific Research Vol. 2 (4) hh.3289-3293

[17] Zeraide, W \& Mulyanto, E. Tanpa Tahun. Penerapan Metode Forward Chaining dengan Teknik Representasi Rule Based Reasoning untuk Diagnosa Kerusakan Mobil Berbasis Android. Semarang: Universitas Dian Nuswantoro. 